\title{
Peningkatan Kuantitas dan Kualitas Produksi Kerupuk Basa di Desa Jegu, Kabupaten Tabanan
}

\author{
Made Agus Putra Subali*1, I Gusti Rai Agung Sugiartha², Arya Faisal Akbar ${ }^{3}$ \\ 1,2,3 Program Studi Sistem Informasi, Fakultas Informatika dan Komputer, \\ Institut Teknologi dan Bisnis STIKOM Bali \\ *e-mail: madeagusputrasubali@gmail.com ${ }^{1}$
}

\begin{abstract}
The partner in this program is the home industry of "basa" crackers or seasoning crackers. There are several partner problems, 1) Long production time, 2) Simple and conventional product packaging, 3) Profit sharing from product marketing. The solutions to overcome these problems are, 1) Providing production equipment, 2) Installing packaging label, 3) Promotion through facebook. The results are, 1) The partner is able to accelerate and increase production quantity where in single production, the partner can produce more than 105 packs of basa crackers. 2) Product quality is better with packaging label. 3) Promotion through facebook can expand market share.
\end{abstract}

Keywords: basa crackers, quantity and quality of production, online marketing

\begin{abstract}
Abstrak
Mitra dalam program kemitraan masyarakat kami adalah industri rumah tangga pangan kerupuk basa atau kerupuk bumbu. Terdapat beberapa permasalahan yang dihadapi oleh mitra, 1) Proses produksi yang lama, 2) Kemasan produk masih sederhana dan konvensional, 3) Adanya pembagian komisi dari pemasaran produk dengan cara menitipkannya di beberapa warung. Adapun solusi untuk mengatasi permasalahan mitra, 1) Memberikan bantuan alat produksi, 2) Pemasangan label kemasan, 3) Promosi melalui media sosial facebook. Hasil kegiatan yang telah dicapai, 1) Mitra mampu mempercepat dan meningkatkan jumlah produksi dimana dalam sekali produksi mitra dapat memproduksi lebih dari 105 bungkus kerupuk basa. 2) Produk lebih berkualitas dengan adanya label kemasan. 3) Promosi melalui media sosial facebook mampu memperkenalkan produk mitra ke pasar yang lebih luas.
\end{abstract}

Kata kunci: kerupuk basa, kuantitas dan kualitas produksi, media promosi online

\section{PENDAHULUAN}

Industri rumah tangga merupakan tulang punggung sistem ekonomi kerakyatan yang memberi kontribusi dalam mempercepat peningkatan perekonomian dan ketahanan ekonomi nasional (Zuhri, 2013). Industri rumah tangga yang menjadi mitra adalah industri rumah tangga pangan kerupuk basa atau kerupuk bumbu yang dimiliki oleh Ni Nengah Werki yang berlokasi di br. Ngis, kel. Jegu, kec. Penebel, kab. Tabanan. Usaha mitra berdiri sejak tahun 2007. Dalam sekali produksi mitra dapat mengolah $1 \mathrm{~kg}$ tepung terigu, $1 \mathrm{~kg}$ tepung kanji, $0.2 \mathrm{~kg}$ bawang putih, $0.2 \mathrm{~kg}$ bawang merah, dan $0.3 \mathrm{~kg}$ cabai. Proses pembuatan kerupuk basa dimulai dari menumbuk bumbu hingga halus, kemudian mencampur adonan tepung beserta bumbu yang telah dihaluskan, proses pencampuran adonan dilakukan secara manual menggunakan tangan. Setelah adonan tercampur rata, adonan kemudian dikukus selama dua hingga tiga jam, alat yang digunakan untuk mengukus menggunakan tungku kayu bakar. Setelah selesai dikukus, adonan didiamkan selama satu malam, setelah adonan mengering, adonan kemudian diiris tipis dan dijemur di bawah sinar matahari selama satu hari, jika cuaca mendung proses penjemuran dapat berlangsung hingga beberapa hari, terlihat pada Gambar 1, mitra sedang mengiris adonan dan menjemur kerupuk basa di bawah sinar matahari. Setelah proses penjemuran selesai, kerupuk basa yang telah kering kemudian digoreng dan dikemas. Proses pengemasan produk masih konvensional, produk dikemas menggunakan plastik dan diikat secara manual, terlihat pada Gambar 2, mitra sedang menggoreng kerupuk basa serta kerupuk basa olahan mitra yang telah dikemas. Jumlah dalam sekali produksi sebanyak 70 bungkus kerupuk basa. Hasil produksi dipasarkan dengan cara menitipkan produk di beberapa warung atau kios di sekitar tempat tinggal mitra. Satu bungkus kerupuk basa dihargai seribu rupiah. 
Terdapat beberapa permasalahan yang selama ini dihadapi oleh mitra terutama permasalahan di bidang produksi dan pemasaran. Seperti contoh, lamanya proses produksi, kemasan produk yang masih konvensional, hingga pemasaran produk yang hanya dipasarkan di warung atau kios di sekitar tempat tinggal mitra dengan cara dititipkan. Lamanya proses produksi, dikarenakan pada saat mencampur adonan serta menghaluskan bumbu masih menggunakan cara manual dan alat produksi sederhana, selain itu merebus campuran adonan dan menggoreng kerupuk basa masih menggunakan tungku kayu bakar. Hal lain yang memakan banyak waktu adalah proses penjemuran adonan yang sangat tergantung pada terik sinar matahari. Bahan untuk mengemas kerupuk basa masih sangat konvensional, kerupuk basa dikemas menggunakan plastik yang terikat secara manual serta tanpa adanya label kemasan. Pemasaran produk dilakukan dengan cara menitipkan kerupuk basa di warung serta kios di sekitar tempat tinggal mitra, saat ini terdapat empat warung atau kios yang memasarkan produk mitra. Dalam sekali produksi mitra menghasilkan 70 bungkus kerupuk basa, di mana setiap warung atau kios diberikan 13 hingga 17 bungkus kerupuk basa. Setiap warung atau kios diberikan komisi sebesar 23\% dari hasil penjualan.

Usaha mitra memiliki potensi untuk lebih berkembang, dikarenakan kerupuk basa olahan mitra disukai oleh pelanggan karena memiliki rasa autentik basa atau rasa bumbu. Selama satu minggu mitra dapat memproduksi sebanyak 140 bungkus kerupuk basa atau dua kali produksi dalam seminggu. Namun, jumlah pesanan kerupuk basa dalam seminggu dapat meningkat terutama di hari libur dan akhir pekan hingga 50\% atau 210 bungkus kerupuk basa dalam seminggu. Adapun solusi permasalahan yang telah disepakati bersama mitra akan dilakukan dengan cara ekstensifikasi (pemberian alat bantu produksi) untuk mempercepat proses produksi serta meningkatkan kuantitas produksi (Puspitawati et al., 2018), (Kusuma \& Wedasari, 2019), (Pratama et al., 2020), rasionalisasi (menciptakan label kemasan) untuk meningkatkan kualitas produk dan menarik minat beli konsumen (Suartana et al., 2018), (Suniantara et al., 2019), (Sipahutar et al., 2020) sedangkan untuk memperluas pemasaran, selain dipasarkan di warung dan kios di sekitar tempat tinggal mitra, pemasaran produk turut dilakukan secara online menggunakan sarana media sosial facebook (Efendi et al., 2018), (Purwana et al., 2017).

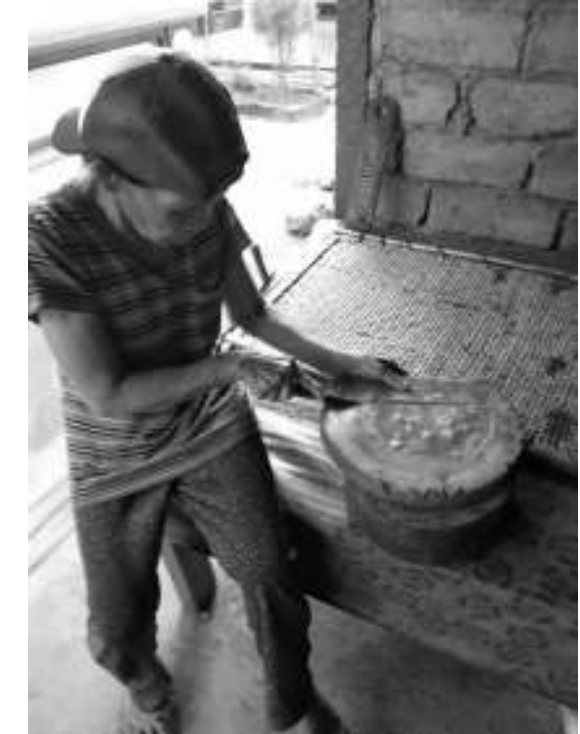

(a)

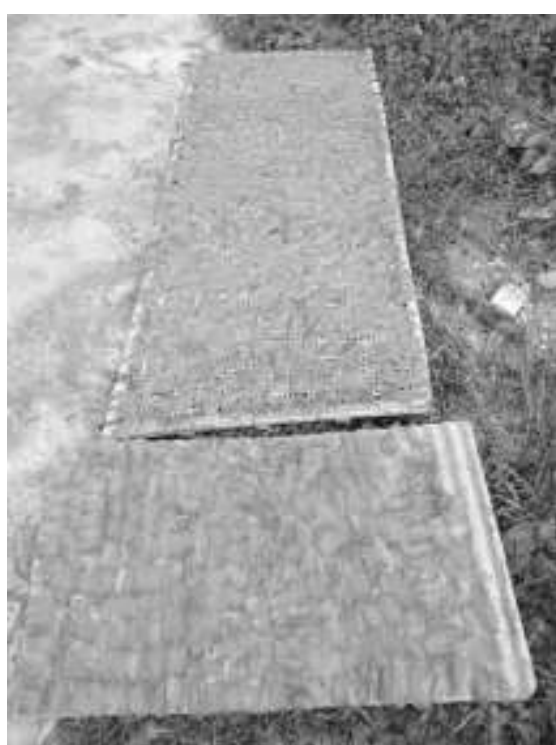

(b)

Gambar 1. Proses Mengiris Adonan (a) serta Proses Penjemuran Kerupuk Basa di Bawah Sinar Matahari (b), Proses Penjemuran dapat Berlangsung selama Satu Hari 


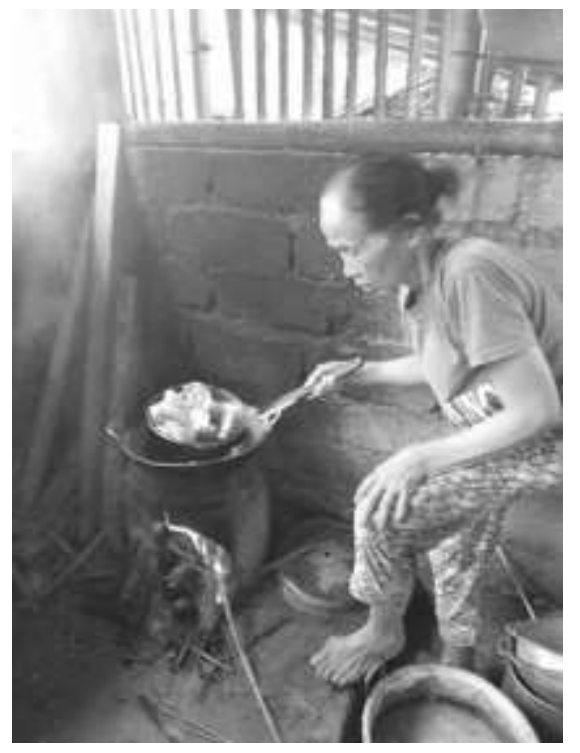

(a)

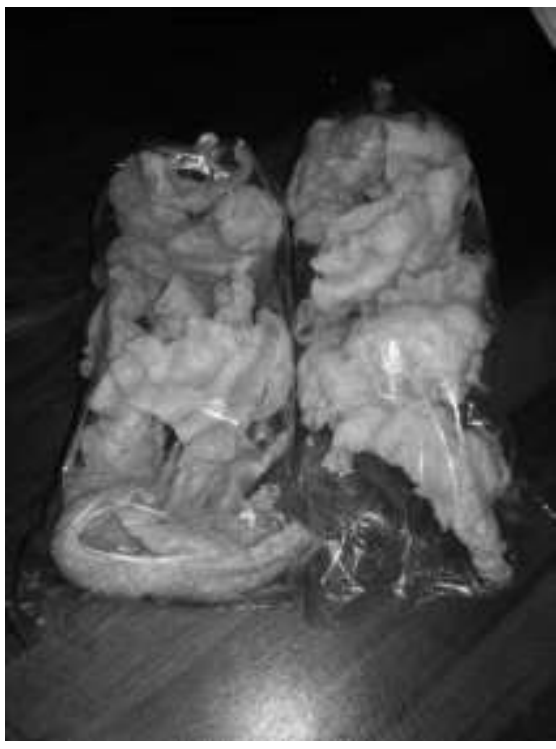

(b)

Gambar 2. Mitra sedang Menggoreng Kerupuk Basa menggunakan Tungku Kayu Bakar (a) dan Kerupuk Basa Olahan Mitra dengan Kemasan yang Konvensional (b)

\section{METODE}

Pada Gambar 3 merupakan tahapan metode pelaksanaan kegiatan dimulai dari sosialisai ke mitra, pemberian bantuan alat produksi, penggunaan alat produksi, pengemasan produk, dan penggunaan media sosial facebook.

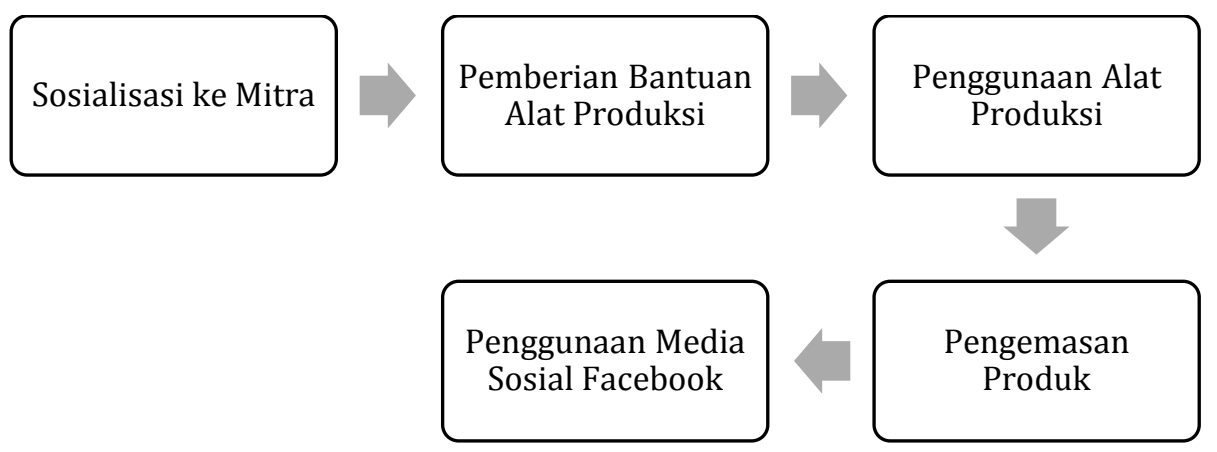

Gambar 3. Tahapan Metode Pelaksanaan Kegiatan Pengabdian

\section{1) Sosialisasi ke Mitra}

Kegiatan sosialisasi bertujuan untuk memberikan informasi terkait kegiatan pengabdian yang akan dilakukan. Serta berdiskusi dengan mitra untuk mengetahui permasalahan prioritas dan solusi untuk mengatasi permasalahan tersebut. Partisipasi mitra dalam kegiatan pelaksanaan program ini amat baik, seperti mitra menyediakan tempat pertemuan, ikut bersosialisasi dengan para anggota keluarga terkait tahapan pelaksanaan yang dilakukan, serta komitmen mitra untuk mengikuti pelaksanaan kegiatan pengabdian secara maksimal.

\section{2) Pemberian Bantuan Alat Produksi}

Pemberian bantuan alat produksi bertujuan untuk mempercepat proses produksi dan meningkatkan kuantitas produksi. Adapun bantuan alat produksi yang diberikan, antara lain:

- Satu unit kompor gas dua tungku.

- Satu unit mixer adonan kue.

- Satu unit blender 1.2 liter 4 in 1. 
- Dua unit panci kukus.

- Dua unit alat penggorengan.

- Tiga unit pisau 8 inci.

- Dua unit sendok jepitan dengan tirisan minyak.

- Empat unit baskom penirisan stainless.

- Dua unit talenan plastik anti-bacterial.

- Satu unit alat press kemasan plastik manual.

- Dua kemasan plastik press pp bening $10 \mathrm{~cm} x 15 \mathrm{~cm}$.

- Satu unit selang dan regulator gas.

- Satu unit LPG 3 kg.

- Dua rim kertas HVS A4 80 gsm.

- Satu tinta printer HP 680 hitam.

\section{3) Penggunaan Alat Produksi}

Pelatihan penggunaan alat produksi bertujuan untuk melatih kemampuan mitra dalam penggunaan alat produksi, seperti penggunaan kompor gas dua tungku untuk proses merebus adonan dan menggoreng kerupuk basa, penggunaan mixer untuk mencampur adonan, dan penggunaan blender untuk menghaluskan bumbu.

\section{4) Pengemasan Produk}

Pengemasan produk diawali dengan menciptakan label kemasan berukuran $6 \mathrm{~cm} \times 5 \mathrm{~cm}$. Kerupuk basa serta label kemasan kemudian dimasukkan ke dalam plastik pp bening berukuran $10 \mathrm{~cm} \times 15 \mathrm{~cm}$ dan direkatkan menggunakan alat press kemasan plastik.

\section{5) Penggunaan Media Sosial Facebook}

Pembuatan akun media sosial facebook dan memberikan pelatihan cara mengelola akun media sosial facebook sebagai media promosi online. Pelatihan yang diberikan meliputi cara login, menambah postingan baru, membalas komentar pengunjung, dan logout.

\section{HASIL DAN PEMBAHASAN}

Hasil yang diharapkan berdasarkan kegiatan pengabdian yang telah dilakukan adalah peningkatan kuantitas dan kualitas produksi kerupuk basa. Dalam usaha peningkatan kuantitas produksi dilakukan dengan memberikan bantuan alat produksi serta pelatihan cara penggunaannya. Hasilnya, mitra mampu mempercepat proses produksi terutama pada proses menghaluskan bumbu, mencampur adonan, merebus adonan, dan menggoreng kerupuk basa. Sehingga kuantitas dalam sekali produksi yang sebelumnya hanya menghasilkan 70 bungkus kerupuk basa, saat ini dapat menghasilkan lebih dari 105 bungkus kerupuk basa. Pada Gambar 4 merupakan kegiatan serah terima bantuan alat produksi dan pada Gambar 5, mitra sedang berlatih menggunakan bantuan alat produksi. 

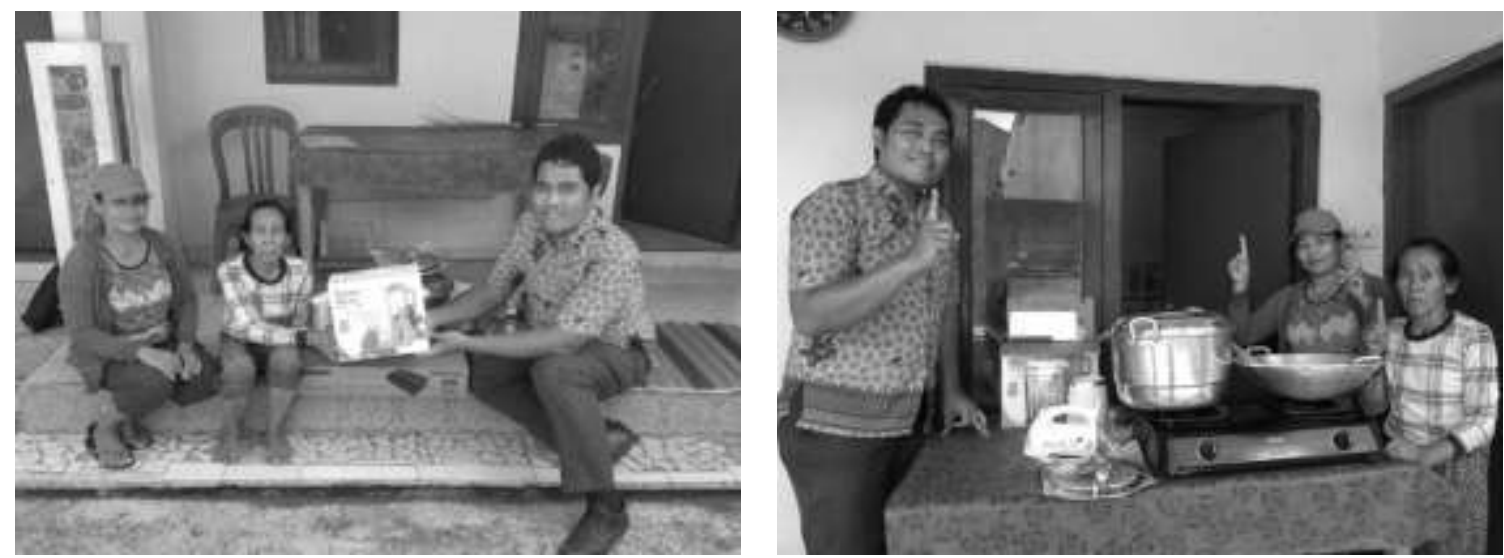

Gambar 4. Serah Terima Bantuan Alat Produksi

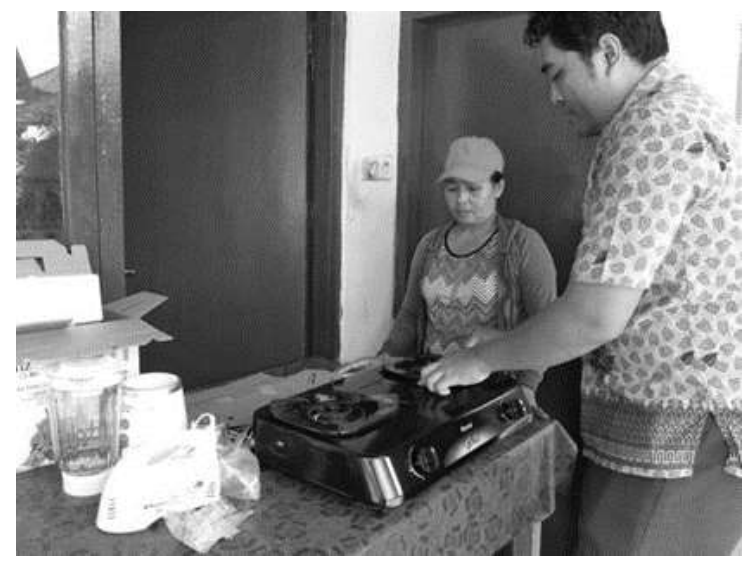

(a)

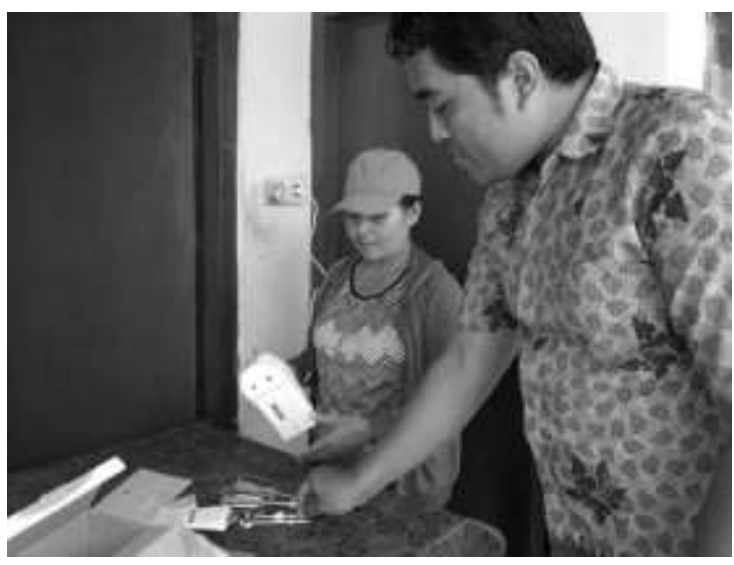

(b)

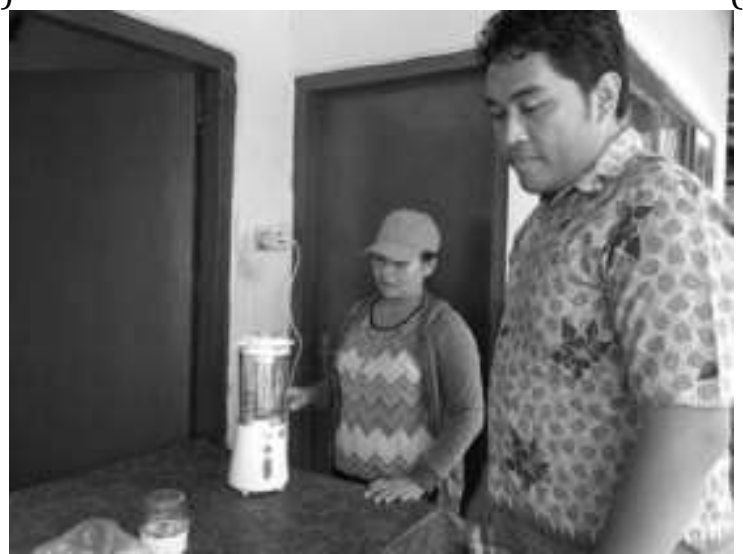

(c)

Gambar 5. Pelatihan Penggunaan Bantuan Alat Produksi Kompor Gas Dua Tungku (a), Mixer (b), dan Blender (c)

Sedangkan dalam usaha peningkatan kualitas produksi dilakukan dengan menciptakan label kemasan serta pengemasan menggunakan alat press kemasan plastik. Berdasarkan hasil penelitian terdahulu pendekatan rasionalisasi atau menciptakan label kemasan dapat meningkatkan kualitas produk dan menarik minat beli konsumen (Suartana et al., 2018), (Suniantara et al., 2019). Pada Gambar 6 merupakan kemasan lama produk beserta produk dengan label kemasan baru. 


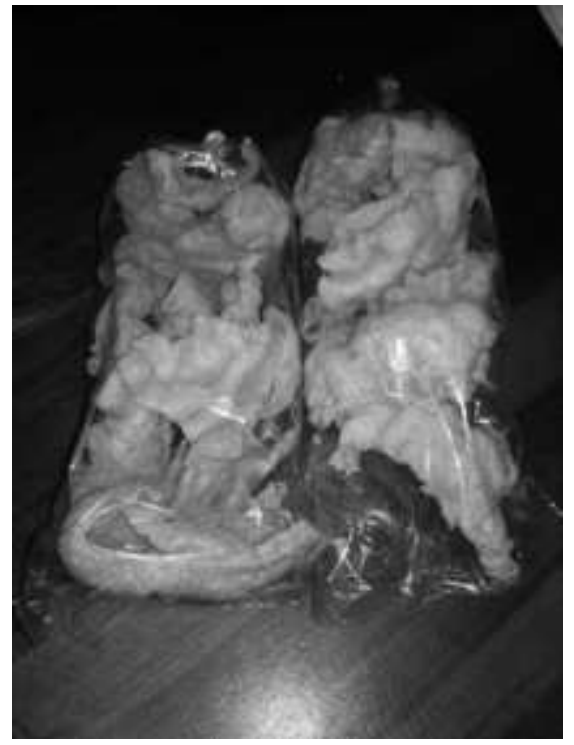

(a)

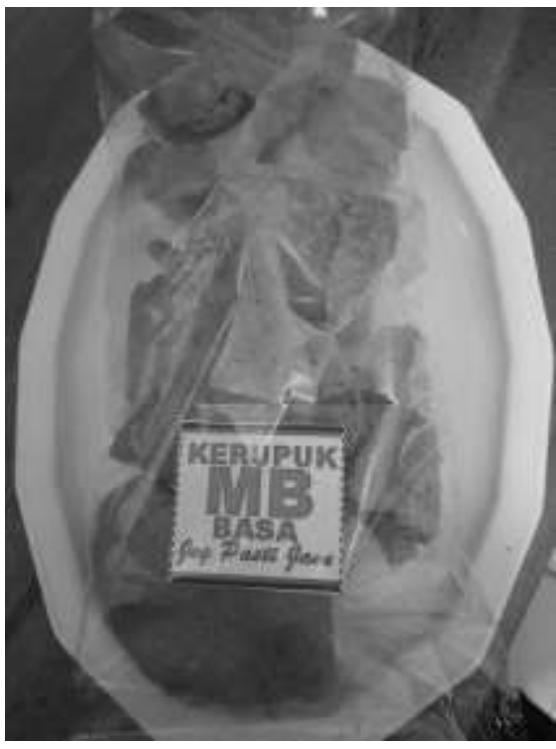

(b)

Gambar 6. Kemasan Lama Kerupuk Basa (a) dan Kemasan Baru Kerupuk Basa (b)

Dalam pemasaran produk turut dilakukan melalui media sosial facebook, hal ini dilakukan guna memperkenalkan produk mitra pada pasar yang lebih luas. Diharapkan, di masa depan pemasaran produk melalui media online dapat meningkatkan penjualan kerupuk basa mitra, sehingga keuntungan yang diperoleh dapat lebih maksimal tanpa adanya pembagian komisi dengan warung tempat mitra menitipkan produknya. Pada Gambar 7 merupakan screenshot media sosial facebook produk kerupuk basa mitra.

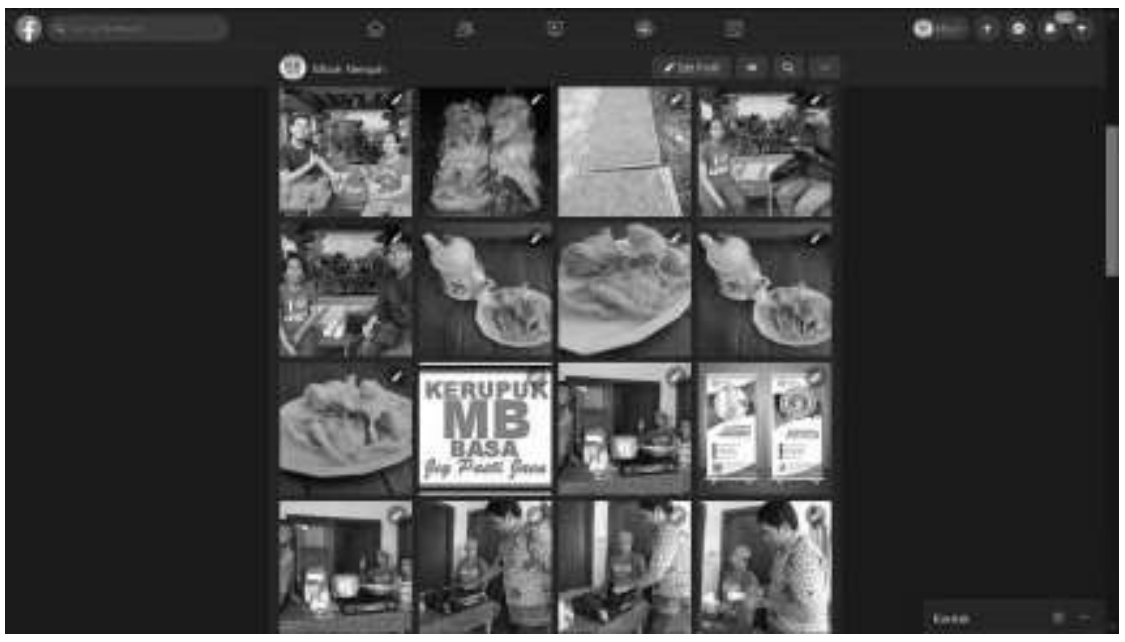

Gambar 7. Halaman Media Sosial Facebook Kerupuk Basa Mitra

\section{KESIMPULAN}

Kesimpulan dari kegiatan yang telah dilakukan adalah sebagai berikut:

- Mitra mampu mempercepat proses produksi terutama pada proses mencampur, mengukus, dan menggoreng adonan kerupuk basa, sehingga kuantitas produksi kerupuk basa dapat meningkat lebih dari 105 bungkus dalam sekali produksi.

- Produk kerupuk basa mitra menjadi lebih berkualitas dengan adanya label kemasan serta penggunaan media sosial facebook dapat mempromosikan ke pangsa pasar yang lebih luas. 
- Pada kegiatan di masa akan datang, pendekatan lain seperti penambahan variasi rasa produk (Andayani et al., 2014) akan dilakukan.

\section{UCAPAN TERIMA KASIH}

Penulis mengucapkan terima kasih kepada Institut Teknologi dan Bisnis STIKOM Bali yang telah memberi dukungan finansial terhadap pengabdian ini.

\section{DAFTAR PUSTAKA}

Andayani, S., Tjahyono, E., \& Sajio. (2014). Peningkatan Kuantitas dan Kualitas Produk pada Perajin Batik Dukuh Kupang Kota Surabaya. Jurnal Pengabdian LPPM Untag Surabaya, 01(01), 41-51.

Efendi, M. R., Wahyuni, S., \& Zulianto, M. (2018). Pengaruh Facebook Sebagai Social Media Marketing Terhadap Perilaku Konsumtif Mahasiswa. Jurnal Pendidikan Ekonomi: Jurnal Ilmiah Ilmu Pendidikan, Ilmu Ekonomi, Dan Ilmu Sosial, 12(1), 82-87.

Kusuma, I. G. N. A., \& Wedasari, N. L. N. M. (2019). Pendampingan dan Peningkatan Produksi IRT - Kue Bugis Desi di Desa Tuakilang Tabanan. WIDYABHAKTI Jurnal Ilmiah Populer, 1(3), 3540.

Pratama, A. K. Y., Wisdaningrum, O., \& Nugrahani, M. P. (2020). Pendampingan dan Penerapan Teknologi Untuk Peningkatan Produktivitas Usaha Mikro Gula Semut. DINAMISIA: Jurnal Pengabdian Kepada Masyarakat, 4(2), 275-284.

Purwana, D., Rahmi, \& Aditya, S. (2017). Pemanfaatan Digital Marketing bagi Usaha Mikro, Kecil, dan Menengah (UMKM) di Kelurahan Malaka Sari, Duren Sawit. Jurnal Pemberdayaan Masyarakat Madani (JPMM), 1(1), 1-17.

Puspitawati, N. M. D., Wijaya, I. M. H., \& Paramita, I. A. P. U. (2018). PKM Kelompok Usaha Olahan Kacang untuk Oleh-Oleh Khas Bali. SINAPTEK, 87-96.

Sipahutar, H., Sirait, M., Harahap, M. H., Irfandi, Panggabean, D. D., Anggriyani, \& Syah, D. H. (2020). Peningkatan Kualitas Tahu Mbak Trisni Di Kecamatan Percut Sei Tuan. DINAMISIA: Jurnal Pengabdian Kepada Masyarakat, 4(2), 384-390.

Suartana, I. K., Purniawan, I. M. E., \& Wiradnyani, N. K. (2018). PKM Loloh Kunyit di Desa Pejeng Kelod Tampaksiring Gianyar. SINAPTEK, 145-156.

Suniantara, I. K. P., Putra, I. G. E. W., \& Hutajulu, S. (2019). Pelatihan Pengolahan dan Pengemasan Kacang Mentik di Desa Bukit. WIDYABHAKTI Jurnal Ilmiah Populer, 1(2), 2125.

Zuhri, S. (2013). Analisis Pengembangan Usaha Kecil home Industri Sangkar Ayam Dalam Rangka Pengentasan Kemiskinan. Manajemen Dan Akuntansi, 2(3), 46-65. 